\section{Storytelling with Older Children: a reflection on practice}

\section{Michael Wilson}

$I^{\prime}$ started school in 1968, first in Denton, to the east of Manchester, and then a year later twelve miles away in the town of Bolton, the birthplace of the Industrial Revolution. It was at the time of the emergence of the alternative theatre movement in Britain, in the aftermath of the political optimism of 1968 and I was fortunate enough to attend a school in whose town the new theatre-in-education movement was thriving. I can remember a number of visits by theatre companies during my years at primary school, although after my move to secondary school at the age of eleven, there were no such visits. At that point no doubt the frivolity of theatre had to limit itself to being an extra-curricular activity, as we settled down to the more serious business of education ${ }^{1}$. At no time during my entire school career, which lasted thirteen years, did I ever encounter a storyteller. The first time I met a storyteller was shortly before coming one myself.

Of course, things are very much different now. There is probably not a single child graduating from British schools these days who has not benefited from a storyteller visiting their school at some point. Nevertheless for most that experience is still confined to the years of their primary education. In spite of the introduction of the National Curriculum, we have found it difficult to shake the belief that the triviality of telling stories has no place in a secondary education system that attaches greater value to the business of literary criticism. The unfortunate regime of regular, standardized testing of pupils has done nothing to help either, as teachers are given little opportunity to be creative with the curriculum.
Such is the pressure upon teachers in all subject areas to deliver their part of the curriculum, that few are prepared to relinquish time on a regular basis for storytelling and what is primarily seen as part of the English or Drama curriculum.

During my time as a professional storyteller the vast majority of my work was within schools and libraries. To some degree, I was governed by the demands and expectations of my clients and I readily admit, on many occasions, of doing unimaginative work and filling the role of class entertainer, because that was all that was demanded of me. I'm sure it had some real value, but there were probably far too many of those occasions for my liking and they were almost exclusively at primary school level.

The work that I am most proud of is the storytelling initiative I accomplished in secondary schools, mainly with the 11-14 age group. At the time I made a small reputation for working with this age group, not least because there were relatively few storytellers working in secondary schools. Teenagers were wary of storytellers and storytellers were certainly wary of teenagers. However, I found this work most rewarding mainly because many of the teachers I worked with were very happy to try something new. They knew that storytelling was just as important to this age group as it was to the under 11s, but they also felt that simply having a storyteller tell stories to them might no be the best way forward. Teachers felt that the pupils themselves might feel patronized by such an approach. It meant that I had much greater freedom to work imaginatively.
The first time I was invited to work in a secondary school I was extremely nervous. In fact, I may not even have accepted the engagement had I not been in need of a new car. As it turned out, something happened at the end of each of the four sessions that day that had never happened at any primary school I had visited. Dozens of children during the course of the day approached me to tell me stories that they knew. Some were jokes, some were riddles, some were personal anecdotes or family stories. Many were ghost stories or variants of well-known contemporary legends. What is more interesting is as I started to visit more and more secondary schools, the experience repeated itself. I soon realized that, contrary to popular opinion (including the opinion of many storytellers and teachers), teenagers were active storytellers of their own contemporary and traditional folklore. Out of curiosity I started to take a small hand-held tape recorder into the schools with me and began to record the teenagers' stories. Before long I had a sizeable archive, which eventually led to my doctoral research, but it caused me to ask some fundamental questions about the storytelling work that I was doing. If these pupils were active, and indeed proficient, storytellers in their own right, then what was it I was hoping to achieve by my work, and what could I do to encourage and enable the teenagers I was working with, in the short space of time I had available to me, to become, what Zipes calls, 'storytellers of their own lives'? My purpose was, I decided, not to blind them with the brilliance of my own artistry as a storyteller, but rather to increase an awareness of their own storytelling culture and artistry, to show them that their stories were important and no matter whether their tales, liberally spiced with horror, the supernatural and scatological humour, were dismissed as trivial by adults, they really did matter. As a result I designed a programme that fulfilled the expec- 
tations of the teachers of a session by a professional storyteller, but always aimed, by the end of the hour, to have descended into the anarchy of the pupils noisily telling their stories to each other or, more usually, constantly interrupting me in order to tell their stories to the assembled class. The success of the session I always judged by the extent to which I had made myself completely dispensable and the students had taken creative control for themselves. In many ways it was an exercise in empowerment and democracy.

The session always began, naturally enough, with a preamble of about fifteen minutes in length, during which time I would introduce myself and ask them what they thought I was going to do and what kind of stories they thought I would tell. I might tell them a couple of jokes and ask them if they thought that jokes were stories. There would be some discussion and even a vote on the issue. From there I would ask them a few riddles and teach them a few more that they could take home and try out on their parents or brothers and sisters. This was primarily all in aid of establishing a relationship of trust, of befriending them. Before long I would turn the attention to ghost stories and tell them a couple of such stories, one short and one long, probably a contemporary legend or a memorate (personal ghost story) and a longer traditional narrative ('Apple and Orange', a Scottish variant of 'The Juniper tree' was always a favourite). In fact, very often they weren't even ghost stories, strictly speaking, but may simply have been stories with elements of horror or the macabre in them. Either way, they were always ones that I knew would spark an association with some of the audience, because by this time I had become very familiar with the classics in the teenage repertoire. I was confident that if I told a particular story (and dropped in enough clues to boot) then as I finished a sea of hands would go up with cries of 'I know one like that!'

That was usually all that was needed for the session to take on a life of its own. Somebody would tell their story and usually another student would challenge that particular version and tell their own variant of the same story. Discussions and arguments would inevitably follow and, for my part, I would add some contextual information for them, trying to relate it to other narratives, illustrating how their storytelling was part of a much wider tradition of storytelling. Once we had exhausted the variants of one particular story, somebody would inevitably volunteer another story or, failing that, I would ask a question that I knew would prompt another story. On nearly every occasion the bell for the end of the session would sound whilst the storytelling was in full swing.

Now, I am not claiming that this was exemplary storytelling practice - in concert with the teachers I was often making it up as I went along, and one is often sailing close to the wind with teenagers when dealing with the subject matter of their own folk narratives - but it was exciting work that was rarely being done elsewhere and, more importantly, most of the pupils went away enthused. I know that, because I would catch snatches of stories being exchanged between pupils at lunchtime and as I was leaving at the end of the day. If I was able to return to the school, I was welcomed back with a sense of anticipation, not trepidation. In the best cases, where I was able to make a series of visits (all too rarely) or where teachers were determined to follow up the visit in a systematic manner, informal storytelling clubs were established. What was most significant was not simply that the teenagers became excited and enthused by storytelling, but that they became excited and enthused by their own storytelling. As we all tell stories to make sense of our experi- ences and the world around us, and to articulate our aspirations and desires (the first step to making our dreams come true), then to realize the full, empowering potential of storytelling, then we must create opportunities for children to tell their own stories, the stories they choose to tell in the way that they choose to tell them. Furthermore, due value and credit must be given to them. Enabling children to become storytellers of their own lives and their own stories is the first step to equipping them to take control of their own destinies. I can't honestly say that we did that here - sixty minutes is not enough to achieve that - but it was, I believe, a step in the right direction.

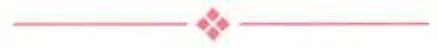

Michael Wilson is a professor and chair of the Drama and Performing Arts at Glamorgan University, Wales. His background in

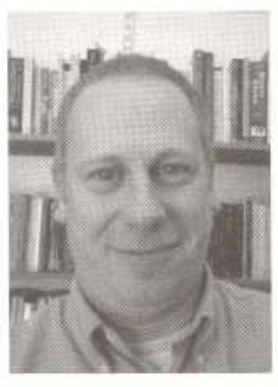
community theatre, storytelling and teaching teachers is extensive. Author of several books and many articles, Dr. Wilson has written for television and theatre. $\mathrm{He}$ is an expert on contemporary legends urban myths and all forms of forteana. His projects with teens and storytelling are described in his book Performance and Practice: Oral narratives Among Teenagers in Britain and Ireland (1997) Ashgate Press. His new book Storytelling and Theatre published by Palgrave will be released soon.

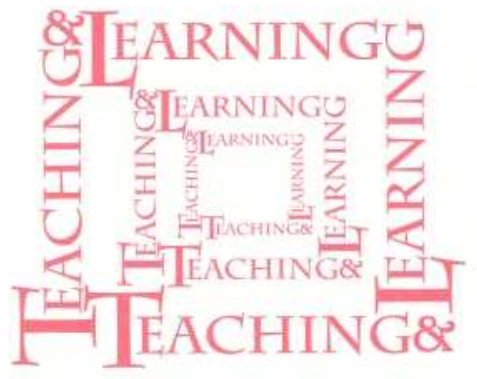

